\title{
TANGGUNG JAWAB DIREKTUR PT PMA YANG TIDAK MENDAPATKAN PENGESAHAN SEBAGAI BADAN HUKUM DAN SUDAH MENJALANKAN USAHANYA BERDASARKAN PERATURAN PERUNDANG-UNDANGAN DI INDONESIA (STUDI KASUS PT.X DAN PT.Y)
}

\author{
I Gede Putra Wijaya \\ (Mahasiswa Program S1 Fakultas Hukum Universitas Tarumanagara) \\ (E-mail: gedeputrawi@gmail.com) \\ Christine S. T. Kansil \\ (Corresponding Author) \\ (Dosen Hukum Perusahaan Fakultas Hukum Universitas Tarumanagara, Meraih Sarjana Hukum dari \\ Fakultas Hukum Universitas Tarumanagara, dan Magister Hukum dari Fakultas Hukum Universitas \\ Tarumanagara Jakarta) (E-mail: christinek_51170@yahoo.co.id)
}

\begin{abstract}
Foreign investors who want to invest in Indonesia must obey the existing rules, namely the Investment Law No. 25 of 2007. The investment law stipulates that if foreign investors want to do business in Indonesia, the foreign investor must establish a company in the form of a legal entity, namely a limited liability company. Requirements for foreign companies can be said as legal entities that must go through the stages of establishing a company until the company ratified by the Ministry of Law and Human Rights. If a foreign company is not a legal entity, the foreign company is not legal and cannot be considered a legal subject in carrying out business activities in Indonesia. Regarding the liability of the foreign company that is to be borne by the private party not by the shareholders because the foreign company is not a legal entity. It is better if foreign investors want to carry out business activities in Indonesia that the business must be in the form of a legal entity in accordance with the investment law's order to comply with the applicable rules and foreign investors can carry out their business activities properly.
\end{abstract}

Keywords : Foreign Investors, Legal Entity, Ratification, Liability 


\section{PENDAhUluAN}

\section{A. Latar Belakang}

Prinsipnya, seseorang mendirikan suatu perusahaan bertujuan untuk menghasilkan keuntungan yang besar. Tujuan pokok dari sebuah perusahaan adalah kegiatan yang menghasilkan produk berupa barang dan penawaran berupa produk jasa. Benang merah suatu perusahaan adalah mendapatkan keuntungan ekonomi dengan maksimal dan sebisa mungkin mengatasi kerugian atau menekan kerugian yang akan terjadi dengan seminimal mungkin.

Di satu sisi, perusahaan memang diakui sebagai satu dari banyaknya penggerak dan penopang perekonomian nasional. Perusahaan berperan dalam meningkatkan pertumbuhan ekonomi nasional dan merupakan bagian dari salah satu aspek penting dalam perekonomian di Indonesia. Perusahaan menciptakan lapangan kerja, produk barang serta jasa yang dihasilkan dari usaha perusahaan, dan pembayaran pajak yang memberikan pendapatan bagi negaranya. Itulah mengapa perusahaan dianggap sebagai manfaat yang sangat besar bagi perekonomian khususnya di Indonesia.

Di sisi lainnya, perusahaan dalam melakukan kegiatan usahanya, sering kali melupakan dan terkadang dengan sengaja meninggalkan prosedur hukum yang harus dilakukan. Perusahaan melupakan dan terkadang dengan sengaja meninggalkan prosedur hukum yang dilakukan dikarenakan perusahaanperusahaan tersebut berpikir proses tersebut lama dan menghambat kegiatan usaha sehingga waktu terbuang percuma ${ }^{1}$.

Dalam Pasal 1 Ayat (1) Undang-Undang Nomor 40 Tahun 2007, disebutkan bahwa: ${ }^{2}$

1 Busyra Azheri, Corporate Social Responsibility: Dari Voluntary Menjadi Mandatory, (Jakarta: Rajawali Pers, 2012), hal.4.

${ }^{2}$ Indonesia, Undang-Undang Nomor 40 Tahun 2007 Lembaran Negara Republik Indonesia Tahun 2007 Nomor 106), Pasal 1 Ayat (1). 
"Perseroan Terbatas, yang selanjutnya disebut Perseroan, adalah badan hukum yang merupakan persekutuan modal, didirikan berdasarkan perjanjian, melakukan kegiatan usaha dengan modal dasar yang seluruhnya terbagi dalam saham dan memenuhi persyaratan yang ditetapkan dalam Undang-Undang ini serta peraturan pelaksanaannya."

Apabila kita melihat KUHD, hal tersebut berbeda, KUHD tidak secara eksplisit menyatakan bahwa Perseroan Terbatas adalah badan hukum, dalam UUPT pada kalimat pertama pasal ini dengan tegas menyatakan bahwa Keberadaan PT diakui sebagai badan hukum dan dianggap sebagai "manusia". Badan hukum kenapa disebut sebagai badan, karena ada hukum yang mengatur dan memang diperlukan keberadaanya sehingga disebut Legal Entity. Oleh karenanya maka disebut "artificial person" atau manusia buatan, atau "person in law" atau "legal person or rechtspersoon"."

Setiap perusahaan di Indonesia yang ingin melakukan kegiatan usaha, sebaiknya harus menjalani beberapa prosedur pendirian perusahaan yang diatur dalam peraturan Indonesia yaitu Undang-Undang No. 40 Tahun 2007 Tentang Perseroan Terbatas dan Undang-Undang No. 25 Tahun 2007 Tentang Penanaman Modal Asing.

Bagi perseroan yang berbentuk badan hukum, seperti perseroan terbatas, secara hukum pada prinsipnya harta bendanya terpisah dari harta benda pendirinya atau pemiliknya ${ }^{4}$

Perseroan Terbatas adalah suatu bentuk badan yang diakui oleh hukum yang menjadi sebagai subyek hukum (rechtspersoon) selain manusia pribadi (natuurlijk

\footnotetext{
${ }^{3}$ I.G Rai Widjaya, Hukum Perusahaan, (Jakarta: Megapoint, 2015) Hal. 127.

4 Munir Fuady, Doktrin-Doktrin Modern dalam Corporate Law dan Eksistensinya dalam Hukum Indonesia, Cetakan Ketiga (Bandung: PT Citra Aditya Bakti, Tahun 2014), hal.2.
} 
persoon). Sebagai subyek hukum, Perseroan Terbatas merupakan pendukung hak dan kewajiban. ${ }^{5}$

Menurut ketentuan UUPT, Perseroan Terbatas memiliki 3 (tiga) tahapan tanggung jawab, yaitu: ${ }^{6}$

a. Pertama, di saat persiapan pendirian Perseroan Terbatas dan pada saat Notaris mendirikan akta Notaris dari Perseroan Terbatas tersebut dan belum mendapatkan pengesahan sebagai badan hukum di Kementerian Hukum dan HAM. Pada tahapan ini, semua pendiri dan pemegang saham akan bertanggung jawab secara pribadi atau tanggung renteng terhadap kerugian perseroan yang akan terjadi ketika melakukan kegiatan usaha.

b. Kedua, apabila Perseroan Terbatas telah mendapat pengesahan sebagai badan hukum namun belum didaftarkan dan juga belum diumumkan, maka pada tahap ini, pemegang saham bertanggungjawab terbatas. Di sini mulai berlaku tanggung jawab terbatas pemegang saham, lalu Direksi dan Komisaris bertanggungjawab secara pribadi atau tanggung renteng.

c. Ketiga, yaitu setelah badan hukum sudah didaftarkan dan diumumkan. Pada tahapan inilah para pemegang saham, Direksi dan Komisaris memiliki tanggung jawab terbatas.

Apabila suatu PT ingin dapat menjalankan fungsinya sebagai rechtpersoon, persyaratannya harus terpenuhi terlebih dahulu. Pertama, para pendiri memiliki

${ }^{5}$ Anonim, Pengesahan Akta dari Menteri Hukum dan HAM, hukumonline.com, 14 Juni 2004. (diunduh pada Rabu, 7 November 2018, pukul 19.54)

${ }^{6}$ Azizah, Hukum Perseroan Terbatas, (Malang: Setara Press, 2016), hal.106129. 
keharusan untuk mendirikan PT berdasarkan akta pendirian PT yang dibuat dihadapan notaris, akta mana mencakup pula anggaran dasar dari PT yang bersangkutan. Selanjutnya para pendiri dan Direksi harus mendapatkan pengesahan atas akta pendirian tersebut dari Menteri Hukum dan HAM. Ketiga, setelah mendapatkan SK dari Kementerian Hukum dan HAM, Direksi lalu mendaftarkan PT (beserta Akta Pendirian) ke Daftar Perusahaan di tempat PT tersebut berdomisili untuk mendapatkan Tanda Daftar Perusahaan, dan mengumumkan Akta Pendirian dalam Tambahan Berita Negara. ${ }^{7}$

Sekarang pertanyaannya adalah kenapa harus kepada Menteri Hukum dan HAM dan bukannya cukup disahkan oleh Notaris saja. Ini benar-benar erat dengan kaitannya pemerintah sebagai fungsi pengawasan, dalam hal ini dilakukan oleh Menteri Hukum dan HAM. Apabila pemeriksaan yang seksama telah dilakukan terhadap akta pendirian dan anggaran dasar PT, harus ditanyakan apakah pendirian PT tersebut tidak bertentangan dengan hukum yang berlaku atau tidak, baru Menteri Hukum dan HAM dapat mengeluarkan surat pengesahan. ${ }^{8}$

Dalam kasus ini PT. X dan PT. Y tidak mendapatkan pengesahan Menteri Hukum dan HAM tetapi sudah melakukan kegiatan usaha dengan menggunakan modal investor yang sangat besar. PT. X mulai didirikan pada hari Jumat, tanggal 24 Juli 1998 di hadapan Notaris di daerah Tabanan, Bali. PT. X didirikan oleh 2 (dua) investor asing yaitu investor dari warga negara Korea dan dari warga negara Jepang. PT. X bergerak di bidang usaha perdagangan umum, industri mebel dan jasa. PT. Y juga didirikan oleh 2 (dua) investor asing yang sama. PT. Y mulai didirikan pada hari Rabu, 26 April 2000. PT. Y didirikan dengan akta pendirian yang dibuat pada Notaris yang sama yaitu Notaris yang membuat akta pendirian PT. X. PT. Y bergerak di bidang usaha perdagangan, pembangunan, hotel, bar, dan restaurant. Kedua PT ini sudah menjalankan usahanya sejak tahun

\section{${ }^{7}$ Ibid. \\ ${ }^{8}$ Ibid.}


didirikannya tetapi tidak mengajukan pendaftaran ke Menteri Hukum dan HAM untuk mendapatkan pengesahan. Akibatnya PT. X dan PT. Y tidak dapat diakui sebagai badan hukum yaitu PT, sedangkan pada aturan yang ada di Indonesia yaitu Pasal 5 Ayat (2) Undang-Undang Nomor 25 Tahun 2007 Tentang Penanaman Modal Asing, untuk 2 (dua) investor asing yang ingin menjalankan usahanya, usaha tersebut harus berbentuk badan hukum yaitu PT dan terdaftar di Menteri Hukum dan HAM. Berdasarkan uraian tersebut di atas maka penulis ingin meneliti bagaimana status hukum dan akibat hukum PT PMA yang tidak mendapatkan pengesahan pendirian badan hukum berdasarkan peraturan perundang-undangan di Indonesia serta bagaimana tanggung jawab direktur PT PMA yang tidak mendapatkan pengesahan sebagai badan hukum dan sudah menjalankan usahanya berdasarkan peraturan perundang-undangan di Indonesia.

Berdasarkan uraian tersebut di atas maka penulis berkehendak untuk melakukan penelitian yang lebih mendalam lagi tentang kasus tersebut yang diwujudkan dalam bentuk penulisan jurnal yang berjudul: “Tanggung Jawab Direktur PT PMA Yang Tidak Mendapatkan Pengesahan Sebagai Badan dan Sudah Menjalankan Usahanya Berdasarkan Peraturan PerundangUndangan di Indonesia". (Studi Kasus PT.X dan PT. Y di Bali)

Adapun dalam penulisan jurnal ini penulis akan membatasi pembahasan yang ditinjau dari Undang-Undang Nomor 1 Tahun 1967 Tentang Penanaman Modal Asing, Undang-Undang Nomor 1 Tahun 1995 Tentang Perseroan Terbatas, Undang-Undang Nomor 40 Tahun 2007 Tentang Perseroan Terbatas dan UndangUndang Nomor 25 Tahun 2007 Tentang Penanaman Modal Asing.

\section{B. Permasalahan}

1. Bagaimana status hukum dan akibat hukum PT PMA yang tidak mendapatkan pengesahan pendirian badan hukum berdasarkan peraturan perundangundangan di Indonesia? 
2. Bagaimana tanggung jawab direktur PT PMA yang tidak mendapatkan pengesahan sebagai badan hukum dan sudah menjalankan usahanya berdasarkan peraturan perundang-undangan di Indonesia?

\section{Metode Penelitian}

\section{Tipe atau Jenis Penelitian}

Tipe penelitian yang akan digunakan oleh Penulis dalam penelitian ini adalah penelitian hukum normatif. Untuk itu diperlukan penelitian yang merupakan suatu rencana pokok dalam pengembangan ilmu pengetahuan. Adapun ruang lingkup dalam penelitian normatif ini adalah menyangkut inventarisasi hukum yakni dengan Undang-Undang Perseroan Terbatas, Undang-Undang Penanaman Modal Asing. Menurut Soerjono Soekanto, penelitian yuridis normatif adalah penelitian hukum dengan cara meneliti bahan pustaka atau data sekunder sebagai bahan dasar untuk diteliti, lalu mengadakan penelusuran terhadap peraturan-peraturan dan literatur-literatur yang berkaitan dengan permasalahan yang diteliti. ${ }^{9}$

Penelitian ini juga ditunjang dengan melakukan wawancara kepada pihak yang terkait yaitu:

a. Kuasa Hukum PT.X dan PT.Y di Bali yaitu I Made Sari.

b. Ahli Hukum Bisnis: Gunawan Widjaja selaku Dosen.

c. Kementerian Hukum dan HAM.

d. Badan Koordinasi Penanaman Modal.

Penulis menggunakan metode ini dikarenakan dalam penelitian hukum normatif, yang diteliti itu hanya bahan pustaka atau data sekunder, yang mungkin mencakup bahan hukum primer, sekunder, dan tersier. ${ }^{10}$

9 Soerjono Soekanto dan Sri Mamudji, Penelitian Hukum Normatif Suatu Tinjauan Singkat, (Jakarta: PT. RajaGrafindo Persada, 2003), Hal. 13-14

${ }^{10}$ Soerjono Soekamto, Pengantar Penelitian Hukum, Cetakan Ke-3, (Jakarta: Penerbit Universitas Indonesia, 2006), Hal. 53 
Dalam penulisan ini, penulis menggunakan pendekatan kasus (case approach). Pendekatan tersebut berangkat melalui pendapat-pendapat dan doktrin-doktrin yang berkembang di dalam ilmu hukum. ${ }^{11}$

\section{Sifat Penelitian}

Penelitian ini bersifat deskriptif analitis, yaitu menggambarkan gejalagejala di lingkungan masyarakat terhadap suatu kasus yang diteliti. ${ }^{12}$ Penelitian ini diharapkan dapat memberikan informasi secara lengkap dan jelas mengenai Tanggung Jawab Direktur PT PMA yang tidak mendapatkan pengesahan sebagai badan hukum dan sudah menjalankan usahanya berdasarkan peraturan perundang-undangan di Indonesia.

\section{Jenis Data dan Bahan Hukum}

Umumnya, penelitian dibedakan dari data yang diperoleh langsung dari masyarakat dengan dari bahan pustaka. ${ }^{13}$ Data yang digunakan dalam penelitian ini yaitu data sekunder yang mana data tersebut diperoleh melalui kepustakaan. Data sekunder yang dipergunakan adalah data sekunder yang bersifat umum, yaitu data yang berupa kalimat-kalimat, arsip, data resmi dan berbagai data lain yang dipublikasikan. ${ }^{14}$ Data sekunder tersebut di antaranya peraturan perundang-undangan, buku-buku, majalah, artikel atau bahan-bahan lain yang berhubungan dengan penelitian yang menunjang. Jenis bahan hukum merupakan turunan dari jenis data sekunder berdasarkan kekuatan mengikatnya.

Jenis bahan hukum dibagi menjadi tiga yang akan digunakan yaitu:

\footnotetext{
${ }^{11}$ Ibid, hal.135

${ }^{12}$ Soerjono Soekanto, Metode Penelitian Hukum, (Jakarta: Universitas Indonesia Press, 1986), hal 9.

13 Soerjono Soekanto, Penelitian Hukum Normatif, Suatu Tinjauan Singkat, (Jakarta: Rajawalipers, 2007), hal.21.

${ }^{14}$ Soerjono Soekanto, Pengantar Penelitian Hukum, Op.Cit., hal 51.
} 
a. Bahan hukum primer, yaitu bahan hukum yang mempunyai kekuatan mengikat berupa peraturan. Lebih lanjut bahan hukum primer dalam penelitian ini yaitu:

1) Undang-Undang Dasar Negara Republik Indonesia Tahun 1945;

2) Undang-Undang No. 1 Tahun 1967 Tentang Penanaman Modal Asing;

3) Undang-Undang No. 1 Tahun 1995 Tentang Perseroan Terbatas;

4) Undang-Undang No. 40 Tahun 2007 Tentang Perseroan Terbatas;

5) Undang-Undang No. 25 Tahun 2007 Tentang Penanaman Modal.

b. Bahan hukum sekunder adalah buku teks karena buku teks berisi mengenai prinsip-prinsip dasar ilmu hukum. Bahan hukum sekunder berarti bahan yang berkaitan dengan bahan hukum primer dan dapat membantu untuk menganalisa, memahami, dan menjelaskan bahan hukum primer meliputi jurnal ilmiah, laporan penelitian dan buku hukum perusahaan, buku hukum perjanjian serta buku hukum penanaman modal.

c. Bahan hukum tersier adalah bahan hukum yang memberikan petunjuk maupun penjelasan atas bahan hukum primer dan sekunder, yang meliputi kamus, biografi dan lain-lain.

\section{Pengumpulan Data}

Teknik pengumpulan data pada penelitian ini adalah studi dokumen atau bahan pustaka. Studi dokumen adalah alat pengumpulan data yang digunakan di dalam penelitian kepustakaan. Di dalam penelitian kepustakaan yang dilakukan ini adalah penelitian yang bersifat normatif dan dalam hal ini Penulis melakukan studi dokumen terkait dengan hal persaingan usaha tidak sehat.

\section{Analisis Data}

Teknik analisis data yang digunakan adalah dengan teknik analisis normatif kualitatif yang mana menguraikan dan menginterpretasikan data dalam bentuk kalimat dengan baik dan benar, memperoleh jawaban singkat 
yang dirumuskan secara deduktif ${ }^{15}$. Menurut analisis data kualitatif ini, hasil penelitian ini akan diuraikan di dalam bentuk kalimat yang disusun secara sistematis dan jelas sehingga dapat diinterpretasikan untuk memperoleh suatu kesimpulan secara deduktif.

\section{PEMBAHASAN}

\section{A. Status Hukum dan Akibat Hukum PT PMA yang Tidak Mendapatkan Pengesahan Pendirian Badan Hukum Berdasarkan Peraturan Perundang- \\ Undangan di Indonesia.}

Status hukum suatu perusahaan penting untuk ditentukan agar kejelasan mengenai suatu perusahaan dalam menjalankan kegiatan berusaha dapat dilihat dan diketahui serta sesuai dan tidak melanggar aturan-aturan yang ada. Status hukum suatu perusahaan, apabila tidak dapat ditentukan, maka perusahaan tersebut tidak memiliki kejelasan mulai dari keberadaannya hingga kesesuaian dengan aturan yang mengatur.

Dalam Pembahasan bagian sub bab ini, Penulis akan menjelaskan sekaligus memberikan analisis terkait dengan status hukum dan akibat hukum PT PMA yang tidak mendapatkan pengesahan pendirian badan hukum berdasarkan peraturan perundang-undangan di Indonesia.

Penulis pertama-tama ingin membahas aturan yang ada terkait dengan status hukum PT PMA yang tidak mendapatkan pengesahan sebagai badan hukum dan sudah menjalankan usahanya berdasarkan peraturan perundangundangan di Indonesia.

Apabila kita melihat aturan nasional yang mengatur mengenai status hukum, maka hal itu terkait dengan pengesahan suatu badan hukum. Pengesahan badan hukum adalah hal yang menentukan bagi suatu badan

15 Soerjono Soekanto, Penelitian Hukum Normatif, Suatu Tinjauan Singkat, (Jakarta: Rajawalipers, 2007), hal.21. 
hukum terkait bagaimana status hukum badan hukum tersebut, apakah badan hukum tersebut sesuai dengan aturan dan layak untuk berusaha, belum sesuai aturan serta belum layak dan harus memenuhi syarat tertentu atau yang dibutuhkan, atau sama sekali tidak layak untuk berusaha.

Bidang usaha suatu perusahaan asing akan menentukan apakah perusahaan tersebut layak berusaha di Indonesia atau tidak. Apabila bidang usaha pada perusahaan tersebut tidak memenuhi persyaratan yang ada pada Daftar Negatif Investasi, maka perusahaan tersebut tidak dapat melakukan kegiatan usaha di wilayah Indonesia. Apabila kita lihat pada kasus ini, PT. X dan PT.Y bidang usahanya telah memenuhi syarat Daftar Negatif Investasi, tetapi yang menyebabkan kedua perusahaan tersebut tidak memiliki status hukum adalah kedua perusahaan tersebut tidak mendaftarkan ke Kementerian Hukum dan HAM.

Mengenai status hukum suatu perusahaan, apabila didirikan oleh dua investor asing dan tidak ada unsur non-asing sama sekali, maka menurut Pasal 1 Undang-Undang Nomor 1 Tahun 1967 Tentang Penanaman Modal Asing dan Pasal 1 Ayat (3) Undang-Undang Nomor 25 Tahun 2007 Tentang Penanaman Modal Asing yaitu, "Pengertian penanaman modal asing di dalam Undang-undang ini hanyalah meliputi penanaman modal asing secara langsung yang dilakukan menurut atau berdasarkan ketentuan-ketentuan Undang-undang ini dan yang digunakan untuk menjalankan perusahaan di Indonesia, dalam arti bahwa pemilik modal secara langsung menanggung risiko dari penanaman modal tersebut." dan "Penanaman modal asing adalah kegiatan menanam modal untuk melakukan usaha di wilayah negara Republik Indonesia yang dilakukan oleh penanam modal asing, baik yang menggunakan modal asing sepenuhnya maupun yang berpatungan dengan penanam modal dalam negeri."

Apabila tidak ada unsur non-asing sama sekali atau perusahaan tersebut menggunakan modal asing sepenuhnya, maka yang harus dilakukan adalah 
mendirikan badan hukum berupa PT dan harus mendapatkan pengesahan dari Menteri Hukum dan HAM (pada saat itu Menteri Kehakiman), hal ini diatur dalam Pasal 5 Ayat (2) Undang-Undang Nomor 25 Tahun 2007 Tentang Penanaman Modal dan Pasal 3 Ayat (1) Undang-Undang Nomor 1 Tahun 1967 Tentang Penanaman Modal Asing yaitu, "Penanaman modal asing wajib dalam bentuk perseroan terbatas berdasarkan hukum Indonesia dan berkedudukan di dalam wilayah negara Republik Indonesia, kecuali ditentukan lain oleh undang-undang." dan "Perusahaan yang dimaksud dalam pasal 1 yang dijalankan untuk seluruhnya atau bagian terbesar di Indonesia sebagai kesatuan perusahaan tersendiri harus berbentuk Badan Hukum menurut Hukum Indonesia dan berkedudukan di Indonesia."

Jadi apabila setiap perusahaan asing yang memiliki modal asing sepenuhnya, apabila ingin melakukan kegiatan usaha di wilayah Indonesia, harus mendaftarkan dahulu ke Kementerian Hukum dan HAM, karena apabila tidak mendapatkan pengesahan walaupun sudah mendirikan PT di hadapan notaris, maka PT tersebut tidak sah dan tidak dapat menjalankan usahanya sebagai subyek hukum.

Meskipun demikian, apabila PT tersebut mempunyai unsur dalam negeri, maka PT tersebut dapat melakukan kegiatan usaha walaupun belum disahkan, tetapi PT tersebut terhadap tanggung jawab akan resiko-resiko yang timbul akibat kegiatan usaha masih ditanggung oleh pihak-pihak yang menjalankan usahanya dan kekayaannya tidak terpisah layaknya berusaha menggunakan badan hukum berupa PT. Hal ini diatur di dalam Pasal 5 Ayat (1) UndangUndang Nomor 25 Tahun 2007 Tentang Penanaman Modal yaitu, "Penanaman modal dalam negeri dapat dilakukan dalam bentuk badan usaha yang berbentuk badan hukum, tidak berbadan hukum atau usaha perseorangan, sesuai dengan ketentuan peraturan perundang-undangan.".

Kelayakan berusaha atau sah tidaknya suatu perusahaan dalam menjalankan kegiatan usaha di Indonesia, dalam konteks ini PT PMA, tersebut 
diatur di dalam Pasal 7 Ayat (6) Undang-Undang Nomor 1 Tahun 1995 Tentang Perseroan Terbatas dan Pasal 7 Ayat (4) Undang-Undang Nomor 40 Tahun 2007 Tentang Perseroan Terbatas yaitu, "Perseroan memperoleh status badan hukum setelah Akta Pendirian sebagaimana dimaksud dalam ayat (1) disahkan oleh Menteri." dan "Perseroan memperoleh status badan hukum pada tanggal diterbitkannya Keputusan Menteri mengenai pengesahan badan hukum Perseroan."

Kelayakan atau sah tidaknya suatu perusahaan dalam menjalankan kegiatan usaha di Indonesia, dalam konteks ini perusahaan PMA juga diatur di dalam Pasal 3 Ayat (1) Undang-Undang Nomor 1 Tahun 1967 Tentang Penanaman Modal Asing dan Pasal 5 Ayat (2) Undang-Undang Nomor 25 Tahun 2007 Tentang Penanaman Modal yaitu, "Perusahaan yang dimaksud dalam pasal 1 yang dijalankan untuk seluruhnya atau bagian terbesar di Indonesia sebagai kesatuan perusahaan tersendiri harus berbentuk Badan Hukum menurut Hukum Indonesia dan berkedudukan di Indonesia." dan "Penanaman modal asing wajib dalam bentuk perseroan terbatas berdasarkan hukum Indonesia dan berkedudukan di dalam wilayah negara Republik Indonesia, kecuali ditentukan lain oleh undang-undang."

Tujuan atas hal tersebut diterangkan dalam penjelasan Undang-Undang Penanaman Modal adalah merupakan salah satu upaya pemerintah dalam memberikan kepastian hukum dalam melaksanakan kegiatan PMA.

Penulis berpendapat bahwa apabila kedua perusahaan ini yang dijalankan oleh investor asing yang berasal dari Korea dan investor asing yang berasal dari Jepang, tidak mendapatkan pengesahan, maka perusahaan ini tidak sah dan tidak dapat menjalankan usahanya sebagai subyek hukum di Indonesia.

Penulis juga berpendapat yang sama dengan Bapak Gunawan Widjaja karena menurut beliau, pendirian PT ini yaitu PT.X dan PT. Y didirikan pada tahun 1998, dilihat juga undang-undang yang mengatur pada saat di masa itu 
yaitu Undang-Undang Nomor 1 Tahun 1967 tentang Penanaman Modal Asing dan Undang-Undang Nomor 1 Tahun 1995.

Bapak Gunawan Widjaja juga menegaskan bahwa terkait dengan status hukum PT. X dan PT. Y, apabila dilihat dari hukum nasional atau aturan hukum di Indonesia, PT. X dan PT. Y tidak sah atau tidak sesuai dengan Undang-Undang yaitu Undang-Undang PMA.

Bapak Gunawan Widjaja juga menyarankan untuk melihat status badan hukum PT.X dan PT. Y pada sisminbakum agar memastikan apakah kedua PT tersebut memang benar tidak ada pengesahannya. Bapak Gunawan Widjaja juga menerangkan jika benar kedua PT tersebut tidak ada pengesahannya berdasarkan sisminbakum dan oleh sebab itu kedua PT tersebut tidak sah atau tidak sesuai dengan aturan nasional Indonesia.

Penulis juga berpendapat sama terkait dengan penejalasan Bapak I Made Sari, ada banyak faktor yang menyebabkan perusahaan tersebut menjalankan usaha sebelum dilengkapi perizinan yang diperlukannya. Faktor-faktornya pada saat itu yaitu karena ingin segera melakukan kegiatan usaha dikarenakan pada saat itu prosedurnya lama untuk melalui perizinan. Pada saat itu juga, proses perizinan lambat sehingga semakin dinilai menghambat dan membuat perusahaan tersebut melakukan kegiatan usahannya. Bapak I Made Sari juga menjelaskan bahwa mungkin investor-investor tersebut ingin menghindari pembayaran pajak.

Mengenai status hukum dan akibat hukum PT PMA yang tidak mendapatkan pengesahan pendirian badan hukum berdasarkan peraturan perundang-undangan di Indonesia yaitu menurut Bapak I Made Sari, kedua PT tersebut yaitu PT. X dan PT. Y menjadi tidak sah keberadaannya, sehingga akibatnya PT tersebut tidak dapat bertindak sebagai subyek hukum seperti misalnya PT tidak dapat membeli tanah untuk tempat usahanya atas nama PT. PT tidak dapat membeli tanah baik untuk hak guna bangunan maupun hak pakai. 
Penulis juga berpendapat seperti apa yang dikatakan oleh Bapak Faraitody Rinto Hakim, Kepala Seksi Dokumentasi dan Pengumuman Badan Hukum Kementerian Hukum dan HAM, kerugian juga akan timbul bagi perusahaanperusahaan itu sendiri karena tidak mendaftarkan ke Kementerian Hukum dan HAM. Walaupun mereka sudah mendirikan PT, menjadi pemegang saham, tapi apabila tidak didaftarkan, fungsi PT untuk menjalankan usaha akan tidak dapat digunakan sehingga akta yang dibuat di hadapan Notaris menjadi percuma.

Akibat dari tidak didaftarkannya perusahaan tersebut pada Kementerian Hukum dan HAM yaitu perusahaan tidak memiliki status hukum, perusahaan tidak dapat menjalankan usaha terkait dengan perizinan dan peminjaman modal ke bank. Perusahaan tersebut juga dapat dikatakan menurut Pasal 5 Ayat (2) Undang-Undang Nomor 25 Tahun 2007 yaitu perusahaan yang tidak sah keberadaannya atau tidak sesuai dengan aturan hukum Indonesia.

Penulis berpendapat sebaiknya apabila perusahaan tersebut masih ingin melakukan kegiatan usaha dengan sesuai aturan dan sesuai aturan, maka lebih baik didaftarkan pada Kementerian Hukum dan HAM terlebih dahulu. Setelah didaftarkan ke Kementerian Hukum dan HAM, maka perusahaan tersebut dapat mendaftarkan ke BKPM dengan membawa pula bukti pengesahan yaitu SK Kementerian Hukum dan HAM, setelah diproses oleh BKPM, maka perusahaan tersebut dapat berkegiatan usaha dengan sesuai aturan karena telah sesuai dengan aturan nasional yang ada di Indonesia

\section{B. Tanggung Jawab Direktur PT PMA yang Tidak Mendapatkan} Pengesahan Sebagai Badan Hukum dan Sudah Menjalankan Usahanya

\section{Berdasarkan Peraturan Perundang-Undangan di Indonesia}

Ada banyak hal yang dapat dilakukan oleh seseorang apabila ingin menjalankan usahanya. Menjalankan usaha bisa dengan mendirikan badan usaha dengan badan hukum (dalam bentuk Perseroan Terbatas) atau badan usaha yang bukan badan hukum. Untuk menjawab permasalahan yang ada 
mengenai berusaha di Indonesia, apalagi konteksnya berusaha dalam bentuk Perseroan Terbatas, Penulis ingin menjawab permasalahan tersebut dengan cara memberikan analisis terhadap kasus yang terjadi di lapangan melalui pembuatan skripsi ini.

Dalam pembahasan bagian sub bab ini, Penulis akan menjelaskan sekaligus memberikan analisis terkait dengan tanggung jawab direktur PT PMA yang tidak mendapatkan pengesahan sebagai badan hukum dan sudah menjalankan usahanya berdasarkan peraturan perundang-undangan di Indonesia.

Sebelum masuk pada analisis, Penulis ingin sedikit menjabarkan mengenai latar belakang yang membuat timbulnya permasalahan.

Kasus ini berawal ketika perusahaan yang didirikan oleh investor asing dari Jepang yang bernama Iida Katsumi yang berkewarganegaraan Jepang, lahir di Jepang dan bertempat tinggal di Higashiogu Arakawaku Tokyo, Japan yang melakukan kerjasama dengan membuat Perseroan Terbatas (PT) bersama investor asing dari Korea yang bernama Han Jung Kuk yang berkewarganegaraan Korea, lahir di Korea dan bertempat tinggal di Ho Ankook Apt Suknam Dong Incheon, Korea. Iida Katsumi dan Han Jung Kuk mendirikan 2 (dua) PT yang akta pendiriannya dibuat di hadapan Notaris I Ketut Mustika Udaya, S.H. yang beralamat di Jalan Kenyeri No. 3 Tabanan. PT tersebut bernama PT. X dan PT. Y.

PT. X mulai didirikan pada hari Jumat, tanggal 24 Juli 1998 di hadapan Notaris di daerah Tabanan, Bali. PT. X didirikan oleh 2 (dua) investor asing yaitu investor dari warga negara Korea dan dari warga negara Jepang. PT. X bergerak di bidang usaha perdagangan umum, industri mebel dan jasa. PT. Y juga didirikan oleh 2 (dua) investor asing yang sama. PT. Y mulai didirikan pada hari Rabu, 26 April 2000. PT. Y didirikan dengan akta pendirian yang dibuat pada Notaris yang sama yaitu Notaris yang membuat akta pendirian PT. X. PT. Y bergerak di bidang usaha perdagangan, pembangunan, hotel, bar, dan restaurant. 
Kedua PT ini sudah menjalankan usahanya sejak tahun didirikannya tetapi tidak mengajukan pendaftaran ke Menteri Hukum dan HAM untuk mendapatkan pengesahan. Akibatnya, PT tersebut tidak dapat menjalankan usahanya sebagai subyek hukum dan tidak memiliki status hukum.

Setelah melihat latar belakang timbulnya permasalahan, Penulis pertamatama ingin membahas teori dan aturan yang ada terkait dengan tanggung jawab direktur PT PMA yang tidak mendapatkan pengesahan sebagai badan hukum dan sudah menjalankan usahanya berdasarkan peraturan perundang-undangan di Indonesia.

Adapun teori-teori mengenai tanggung jawab direksi yaitu sebagai berikut:

\section{a. Teori Fiduciary of Relationship}

Umumnya tanggung jawab direksi berdasarkan hubungan kepercayaan antara direksi dan perseroan. Jika ditelusuri, Fiduciary of Relationship tersebut memiliki 3 (tiga) faktor penting:

1) Prinsip kehati-hatian dalam bertindak bagi direksi (duty of skill and care);

2) Prinsip itikad baik untuk bertindak semata-mata demi kepentingan dan tanggung jawab perseroan (duty of loyalty); dan

3) Prinsip tidak mengambil keuntungan dari kesempatan yang sebenarnya milik perseroan (no secret profit rule doctrine of corporate opportunity).

b. Teori The Business Judgement Rule

Adalah perlindungan untuk direksi atas tuduhan pelanggaran terhadap ketiga prinsip Fiduciary of Relationship di atas, dimana direksi dapat dibebaskan dari tanggung jawab secara pribadi sekalipun tindakannya menimbulkan kerugian bagi perseroan, baik karena salah perhitungan, maupun hal-hal di luar kemampuan yang menyebabkan kegagalan dari tindakan tersebut, dengan alasan tindakan yang diambilnya itu dilakukan 
sebagai keputusan bisnis yang dibuat melalui itikad baik untuk pada akhirnya demi kepentingan perseroan.

c. Teori Piercing the Corporate Veil

Merupakan suatu teori dimana direksi dapat saja bertanggung jawab penuh secara pribadi atas kerugian perseroan, jika yang bersangkutan bersalah atau lalai menjalankan tugasnya dalam melakukan pengurusan perseroan untuk kepentingan perseroan dan sesuai dengan maksud dan tujuan perseroan.

\section{d. Teori Ultra Vires}

Merupakan suatu tindakan direksi yang melebihi kewenangannya sebagaimana ditentukan dalam UUPT dan Anggaran Dasar, dimana terhadap tindakan tersebut dapat dimintakan pertanggung jawaban kepada direksi yang antara lain berdasarkan doktrin Piercing the Corporate Veil.

Menurut ketentuan UUPT, Perseroan Terbatas memiliki 3 (tiga) tahapan tanggung jawab, yaitu:

a. Pertama, di saat persiapan pendirian Perseroan Terbatas dan pada saat Notaris mendirikan akta Notaris dari Perseroan Terbatas tersebut dan belum mendapatkan pengesahan sebagai badan hukum di Kementerian Hukum dan HAM. Pada tahapan ini, semua pendiri dan pemegang saham akan bertanggung jawab secara pribadi atau tanggung renteng terhadap kerugian perseroan yang akan terjadi ketika melakukan kegiatan usaha.

b. Kedua, apabila Perseroan Terbatas telah mendapat pengesahan sebagai badan hukum namun belum didaftarkan dan juga belum diumumkan, maka pada tahap ini, pemegang saham bertanggungjawab terbatas. Di sini mulai berlaku tanggung jawab terbatas pemegang saham, lalu Direksi dan Komisaris bertanggungjawab secara pribadi atau tanggung renteng.

c. Ketiga, yaitu setelah badan hukum sudah didaftarkan dan diumumkan. Pada tahapan inilah para pemegang saham, Direksi dan Komisaris memiliki tanggung jawab terbatas. 
Apabila kita melihat pada aturan nasional yang mengatur untuk 2 (dua) orang asing yang ingin berinvestasi dan melakukan kegiatan usaha di Indonesia, yaitu Undang-Undang Nomor 1 Tahun 1967 Tentang Penanaman Modal Asing dan Undang-Undang Nomor 25 Tahun 2007 Tentang Penanaman Modal Asing, keduanya sama-sama mengatur apabila ingin menjalankan usahannya, harus dalam bentuk badan hukum yaitu Perseroan Terbatas. Dalam Pasal 1 dan Pasal 3 Ayat (1) Undang-Undang Nomor 1 Tahun 1967 Tentang Penanaman Modal Asing, mengatur bahwa:

"Pengertian penanaman modal asing di dalam Undang-undang ini hanyalah meliputi penanaman modal asing secara langsung yang dilakukan menurut atau berdasarkan ketentuan-ketentuan Undang-undang ini dan yang digunakan untuk menjalankan perusahaan di Indonesia, dalam arti bahwa pemilik modal secara langsung menanggung risiko dari penanaman modal tersebut."

"Perusahaan yang dimaksud dalam pasal 1 yang dijalankan untuk seluruhnya atau bagian terbesar di Indonesia sebagai kesatuan perusahaan tersendiri harus berbentuk Badan Hukum menurut Hukum Indonesia dan berkedudukan di Indonesia.".

Dalam Pasal 5 Ayat (2) Undang-Undang Nomor 25 Tahun 2007 Tentang Penanaman Modal Asing juga menegaskan bahwa: "Penanaman modal asing wajib dalam bentuk perseroan terbatas berdasarkan hukum Indonesia dan berkedudukan di dalam wilayah negara Republik Indonesia, kecuali ditentukan lain oleh undang-undang.".

Berdasarkan pasal-pasal di atas, dijelaskan bahwa apabila 2 (dua) investor asing yang menjalankan usahanya harus dalam bentuk badan hukum berupa Perseroan Terbatas. Apabila dilihat pada kasus ini, 2 (dua) investor asing yaitu investor asing dari Jepang dan investor asing dari Korea telah mendirikan 2 (dua) PT, yaitu PT. X dan PT.Y di hadapan Notaris tetapi belum mendaftarkannya ke Kementerian Hukum dan HAM. 
Yang menjadi timbulnya permasalahan adalah ketika kedua PT tersebut tidak mendapatkan pengesahan oleh Kementerian Hukum dan HAM tetapi sudah menjalankan usaha.

Dalam pengertiannya, Perseroan Terbatas berdasarkan Pasal 1 Ayat (1) Undang-Undang Nomor 1 Tahun 1995 Tentang Perseroan Terbatas yaitu, "Perseroan Terbatas yang selanjutnya disebut perseroan adalah badan hukum yang didirikan berdasarkan perjanjian, melakukan kegiatan usaha dengan modal dasar yang seluruhnya terbagi dalam saham, dan memenuhi persyaratan yang ditetapkan dalam Undang-undang ini serta peraturan pelaksanaannya." Pasal 1 Ayat (1) Undang-Undang Nomor 40 Tahun 2007 Tentang Perseroan Terbatas juga menegaskan dalam pengertiannya yaitu, "Perseroan Terbatas, yang selanjutnya disebut Perseroan, adalah badan hukum yang merupakan persekutuan modal, didirikan berdasarkan perjanjian, melakukan kegiatan usaha dengan modal dasar yang seluruhnya terbagi dalam saham dan memenuhi persyaratan yang ditetapkan dalam UndangUndang ini serta peraturan pelaksanaannya."

Masalah yang timbul dalam konteks ini ketika dua perusahana asing yang dijalankan oleh dua investor asing yaitu PT. X dan PT. Y yang dimana investor Korea menjabat sebagai Direktur dan investor Jepang menjabat sebagai Komisaris, menjalakan kegiatan usahanya bertindak sebagai Perseroan Terbatas dengan membuat akta pendirian PT di hadapan Notaris tetapi tidak melakukan pengesahan melalui pendaftaran di Kementerian Hukum dan HAM (pada saat itu Kementerian Kehakiman). Oleh karena itu, dengan tidak dilakukannya pengesahan PT oleh kedua pihak yaitu investor asing dari Korea dan investor asing dari Jepang, maka bentuk usaha yang dijalankan oleh kedua pihak tersebut tidak dapat dikatakan sebagai PT karena belum disahkan di Kementerian Hukum dan HAM (pada saat itu Kementerian Kehakiman).

Begitu juga terhadap setiap perubahan anggaran dasar harus diberitahukan ke Kementerian Hukum dan HAM, dimana di antara perubahan tersebut, harus 
mendapatkan persetujuan dari Kementerian Hukum dan HAM. Lewat cara ini, melihatkan bahwa adanya kepastian hukum terhadap semua tindakan dan kegiatan usaha PT harus sesuai dengan aturan yaitu UU PT. Hal itu tidak bisa dilakukan hanya berdasarkan perorangan saja seperti badan usaha yang tidak berbadan hukum.

Apabila badan usaha tidak berbadan hukum (Perseketuan Perdata) anggaran dasarnya tidak dibutuhkan pengesahan dari Kementerian Hukum dan HAM. Akta pendirian tersebut cukup didaftarkan ke panitera pengadilan berdasarkan domisili badan usaha tersebut.

Hal terpenting dalam menjalankan perusahaan PMA adalah penggunaan modal dan alokasinnya dalam menjalankan tujuan usaha. Apabila kita melihat PT, guna modal untuk kegiatan usaha hanya bisa digunakan lewat persetujuan perseroan yang ditempuh dengan cara dan kesepakatan para pemegang saham yang diatur dalam anggaran dasar.

Jadi keputusan dalam PT merupakan keputusan atas nama perseroan dan tidak bisa dilakukan semata-mata hanya dengan persetujuan satu orang saja. Beda halnya dengan usaha yang tidak berbentuk badan hukum yang mana dapat bertindak dan bertanggung jawab atas nama sendiri. Tentunya jika hal ini terjadi pada perusahaan PMA, maka bentuk usaha tersebut tidak memberikan kepastian hukum terhadap modal yang diinvestasikan oleh asing.

Begitu juga penyertaan modal asing di dalam suatu PT yang dapat membuktikannya dengan adanya saham. Berbeda dengan badan usaha yang tidak memiliki status badan hukum, kepemilikan para pendiri tidak dapat dibentuk dalam bentuk saham tetapi hanya kekayaan perseroan saja yang diatur oleh pendiri itu sendiri.

Alokasi modal dalam bentuk saham ini mempunyai tujuan dan maksud di antaranya menentukan terkait persentase suara dalam mengambil keputusan terhadap tindakan perseroan, menentukan besar dividen dan/atau kerugian 
(tanggung jawab) yang akan diterima atau diderita atas kegiatan usaha perseroan.

Berdasarkan dari pembahasan di atas, Penulis juga ingin berpendapat terkait dengan Tanggung Jawab Terbatas. Pasal 3 Ayat (1) Undang-Undang Nomor 40 Tahun 2007 tentang Perseroan Terbatas menyatakan bahwa, "Para pemegang saham tidak bertanggung jawab secara pribadi atas tindakan PT dan perikatan yang dilakukan oleh PT melebihi dari saham yang dimiliki oleh masing-masing pemegang saham." Yang artinya pemegang saham tidak bertanggung jawab secara pribadi ketika suatu perusahaan sudah dalam bentuk PT.

Namun dalam kasus ini, kedua perusahaan asing ini tidak mendapatkan pengesahan dari Kementerian Hukum dan HAM, sehingga semua resiko akan menjadi tanggung jawab pribadi dari pihak direktur saja atau dari orang yang menjalankan usaha, baik terhadap pengembalian modal ke pemilik atau investor maupun resiko-resiko atas kegiatan yang telah dikerjakan, persis dengan apa yang disampaikan oleh Kuasa Hukum PT. X dan PT. Y yaitu Bapak I Made Sari.

Penulis juga sependapat dengan Bapak Gunawan Widjaja apabila dilihat dari aturan di Indonesia, investor asing, apabila ingin melakukan kegiatan usaha di Indonesia dengan investor asing lainnya tanpa adanya unsur dalam negeri, maka perusahaan tersebut harus berbentuk badan hukum yaitu PT. Apabila dilihat dari contoh kasus yang dipakai pada skripsi ini, dua investor asing ingin melakukan kegiatan usaha dan sudah membuat akta pendirian PT, tetapi tidak mendapatkan pengesahan, akibatnya resiko yang terjadi akan ditanggung oleh pihak pribadi bukan dari pemegang saham perseroan terbatas.

Penulis juga sependapat dengan Bapak Faraitody Rinto Hakim, perusahaan-perusahaan tersebut harus paham terhadap Undang-Undang yang masih berlaku pada saat itu. Di undang-undang tersebut jelas dikatakan bahwa 
suatu badan hukum berupa PT itu harus disahkan di Kementerian Hukum dan HAM.

\section{PENUTUP}

\section{A. Kesimpulan}

Berdasarkan uraian analisis di atas, maka dapat ditarik kesimpulan sebagai berikut:

1. Mengenai status hukum dan akibat hukum PT PMA yang tidak mendapatkan pengesahan pendirian badan hukum berdasarkan peraturan perundang-undangan di Indonesia, Penulis berkesimpulan bahwa status hukum PT.X dan PT.Y sebagai perusahaan asing yang menjalankan kegiatan usahanya di wilayah Indonesia tidak sah dan tidak sesuai dengan peraturan perundang-undangan di Indonesia yaitu Pasal 5 Ayat (2) Undang-Undang Nomor 25 Tahun 2007 Tentang Penanaman Modal.

Akibat Hukum PT PMA yang tidak mendapatkan pengesahan pendirian badan hukum berdasarkan peraturan perundang-undangan di Indonesia yaitu perusahaan asing PT.X dan PT.Y, tidak dapat menjalankan kegiatan usaha di Indonesia sebagai subyek hukum karena berdasarkan ketentuan Pasal 5 Ayat (2) Undang-Undang Nomor 25 Tahun 2007 Tentang Penanaman Modal, setiap perusahaan PMA yang ingin menjalankan usahanya di Indonesia, harus berbentuk badan hukum berupa Perseroan Terbatas.

2. Mengenai tentang tanggung jawab direktur PT PMA yang tidak mendapatkan pengesahan sebagai badan hukum dan sudah menjalankan usahanya berdasarkan peraturan perundang-undangan di Indonesia, Penulis berkesimpulan bahwa semua resiko akan menjadi tanggung jawab pribadi dari pihak direktur saja atau dari orang yang menjalankan usaha, baik terhadap pengembalian modal ke pemilik atau investor maupun resiko-resiko atas kegiatan yang telah dikerjakan karena perusahaan asing tersebut tidak menjalankan kewajibannya yaitu mendaftarkan ke 
Kementerian Hukum dan HAM, sehingga perusahaan tersebut tidak berbentuk badan hukum walaupun sudah membuat akta pendirian PT di hadapan Notaris.

\section{B. Saran}

Berdasarkan Kesimpulan di atas maka saran yang dapat diberikan adalah sebagai berikut:

1. Saran kepada para investor asing, sebaiknya investor asing yang ingin melakukan kegiatan usaha di suatu wilayah, khususnya wilayah Indonesia, memahami aturan-aturan yang mengatur terkait dengan tata cara dan prosedur pendirian perusahaan asing sebelum melakukan kegiatan usahanya tersebut karena apabila tidak memahami aturan yang mengatur terkait dengan pelaksanaan kegiatan penanaman modal asing, kerugian yang ditimbul akan diderita oleh para investor asing itu sendiri, bukan pihak yang lain.

2. Saran kepada Kementerian Hukum dan HAM, sebaiknya Kementerian Hukum dan HAM lebih sering mengadakan sosialisasi mengenai pengesahan suatu badan usaha agar dapat menjadi badan hukum, khususnya dalam pengesahan perusahaan asing, agar praktek-praktek dalam kasus seperti ini dapat diantisipasi dan tidak menimbulkan kerugian yang besar bagi pihak investor yang ingin berinvestasi di Indonesia maupun pihak pemerintah yang mengatur serta mengawasi jalannya kegiatan berinvestasi.

\section{DAFTAR PUSTAKA}

\section{A. BUKU}

Azizah, Hukum Perseroan Terbatas, (Malang: Setara Press, 2016) 
Azheri, Busyra. Corporate Social Responsibility: Dari Voluntary Menjadi Mandatory, (Jakarta: Rajawali Pers, 2012).

Fuady, Munir. Doktrin-Doktrin Modern dalam Corporate Law dan Eksistensinya dalam Hukum Indonesia, Cetakan Ketiga (Bandung: PT Citra Aditya Bakti, Tahun 2014).

Rastuti, Tuti. Seluk Beluk Perusahaan \& Hukum Perusahaan, Cetakan Kesatu (Bandung: PT Refika Aditama, 2015).

Saliman, Abdul R. Hukum Bisnis Untuk Perusahaan: Teori dan Contoh Kasus, Cetakan Keenam (Jakarta: Kencana Prenada Media Group, 2011).

Soekanto, Soerjono. Metode Penelitian Hukum, (Jakarta: Universitas Indonesia Press, 1986).

- Penelitian Hukum Normatif, Suatu Tinjauan Singkat, (Jakarta: Rajawalipers, 2007).

- Pengantar Penelitian Hukum, Cetakan Ke-3, (Jakarta: Penerbit Universitas Indonesia, 2006).

Soekanto, Soerjono dan Sri Mamudji, Penelitian Hukum Normatif Suatu Tinjauan Singkat, (Jakarta: PT. RajaGrafindo Persada, 2003)

Widjaya, I.G Rai. Hukum Perusahaan, (Jakarta: Megapoint, 2015).

\section{B. PERATURAN PERUNDANG-UNDANGAN}

Indonesia, Undang-Undang Nomor 40 Tahun 2007 tentang Perseroan Terbatas (Lembaran Negara Republik Indonesia Tahun 2007 Nomor 106).

Indonesia, Undang-Undang Nomor 1 Tahun 1995 tentang Perseroan Terbatas (Lembaran Negara Republik Indonesia Nomor 3587)

Indonesia, Undang-Undang Nomor 25 Tahun 2007 tentang Penanaman Modal (Lembaran Negara Republik Indonesia Nomor 4724)

Indonesia, Undang-Undang Nomor 1 Tahun 1967 tentang Penanaman Modal (Lembaran Negara Republik Indonesia Nomor 2818) 
I Gede Putra Wijaya \& Christine S. T. Kansil

Tanggung Jawab Direktur PT PMA Yang Tidak Mendapatkan Pengesahan Sebagai Badan Hukum dan Sudah Menjalankan Usahanya Berdasarkan Peraturan Perundang-Undangan di Indonesia

\section{INTERNET}

Anonim. "Pengesahan Akta dari Menteri Hukum dan HAM". www.hukumonline.com, 14 Juni 2004.

Shanti Rachmadsyah, "Pendirian PT PMA". www.hukumonline.com, 24 Juni 2010. 